\title{
PEMBELAJARAN INKUIRI TERBIMBING BERBASIS LINGKUNGAN UNTUK MELATIHKAN KETERAMPILAN PROSES DASAR IPA KELAS II MI MAMBAUL ULUM
}

\author{
Farida Nur Kumala
}

Universitas Kanjuruhan Malang

\begin{abstract}
Abstrak: Pembelajaran IPA di MI Mambaul Ulum menggunakan metode ceramah yang monoton di dalam kelas, hal ini menyebabkan pembelajaran kurang bermakna dan pasif bagi siswa. Pembelajaran inkuiri terbimbing berbasis lingkungan memberikan konsep yang nyata serta dapat melatihkan keterampilan proses yang disyaratkan dalam IPA. Penelitian ini bertujuan untuk mendeskripsikan pelaksanaan pembelajaran inkuiri terbimbing berbasis lingkungan di kelas II MI Mambaul Ulum dan keterlaksanaan keterampilan proses dasar IPA pada materi posisi cahaya matahari. Penelitian ini merupakan penelitian kualitatif deskriptif. Subyek penelitian adalah guru dan siswa kelas II MI Mambaul Ulum. Teknik pengambilan sampel menggunakan teknik purposive sample. Metode pengumpulan data pada penelitian ini adalah teknik observasi, wawancara dan tes. Instrumen yang digunakan adalah lembar observasi, pedoman wawancara dan lembar tes hasil belajar siswa. Teknik analisis data pada penelitian ini yaitu pengumpulan, reduksi, penyajian data dan kesimpulan. Keabsahan data dilakukan dengan proses triangulasi metode pengambilan data dan sumber data Hasil penelitian menunjukkan pelaksanaan pembelajaran inkuiri terbimbing berbasis lingkungan di kelas II diterapkan dengan baik karena sesuai dengan indikator keterlaksanaan model pembelajaran inkuiri terbimbing berbasis lingkungan sebesar 90,9\% dan tercapainya tujuan pembelajaran yang ditandai dengan nilai rata-rata hasil belajar siswa serta keterampilan proses dasar IPA telah terlihat pada semua aspek yang dikembangkan sebesar $71,8 \%-100 \%$.
\end{abstract}

Kata Kunci: Pembelajaran IPA, Berbasis lingkungan, Inkuiri Terbimbing, Keterampilan Proses

Pendidikan merupakan upaya mengkondisikan situasi yang dapa tmengembangkan dan menumbuhkan kemampuan serta peran peserta didik sebagai individu, anggota masyarakat dan umat Tuhan (Pidarta, 2009). Hal ini sesuai dengan tujuan pendidikan nasional yaitu mengembangkan potensi peserta didik agar menjadi manusia yang beriman dan bertakwa kepada Tuhan Yang MahaEsa, berakhlak mulia, sehat, berilmu, cakap, kreatif, mandiri, dan menjadi wargane gara yang demokratis serta bertanggung jawab (BSNP, 2006).

Dalam rangka mencapai tujuan pendidikan nasional, diperlukan suatu acuan dasar oleh setiap penyelenggara dan satuan pendidikan yaitu dengan adanya kurikulum. Struktur kurikulum Sekolah Dasar memuat delapan mata pelajaran yang salah satunya adalah mata pelajaran IPA. Salah satu tujuan 
IPA adalah mengembangkan pengetahuan dan pemahaman konsep-konsep IPA yang bermanfaat dan dapat diterapkan dalam kehidupan sehari-hari, mengembangkan rasa ingin tahu, dan kesadaran tentang adanya hubungan yang saling mempengaruhi antara IPA, lingkungan, teknologi dan masyarakat, serta mengembangkan keterampilan proses untuk menyelidiki alam sekitar (BSNP, 2006

Berdasarkan tujuan IPA, maka pembelajaran IPA lebih diarahkan pada pembelajaran yang aktif dalam mengem-bangkan keterampilan proses IPA dan mampu mengkaitkan antara konsep yang ada di kelas dengan fenomena yang ada dalam kehidupan sehari-hari. Namun, pelaksanaan pembelajaran di Indonesia masih didominasi pandangan bahwa pengetahuan yang diajarkan kepada peserta didik merupakan seperangkat fakta, konsep atau kaidah yang diyakini kebenarannya dan harus dihafal. Guru masih berperan sebagai sumber ilmu pengetahuan sedangkan siswa pasif menerima informasi. Akibatnya, pembelajaran saat ini belum diarahkan pada proses siswa dapat aktif dan kreatif dalam mengkonstruksi pengetahuan yang didapatkannya, terlebih lagi pembelajaran menjadi tidak bermakna karena kurang dipahami oleh siswa.

Salah satu cara untuk mengembangkan pembelajaran yang menciptakan pembelajaran bermakna, dapat dilakukan guru melalui pembelajaran berbasis lingkungan. Pembelajaran berbasis lingkungan adalah pembelajaran yang mengintegrasikan unsur lingkungan dalam proses pembelajaran yang bertujuan untuk membantu peserta didik mendapatkan makna dari pembelajaran (Wiyarsi dan Sari, 2010).

Pembelajaran berbasis lingkungan memungkinkan siswa membuat hubungan antara pengetahuan yang dimiliki dengan penerapannya dengan kehidupan sehari-hari.
Pembelajaran berbasis lingkungan terdiri dari beberapa asas diantaranya pembelajaran berbasis masalah, pembelajaran yang berpusat pada siswa, belajar yang diatur sendiri, pembelajaran konstruktivis dan berorientasi pada kegiatan. Penerapan pembelajaran berbasis lingkungan akan membantu siswa meningkatkan kemampuan berpikir analitis, logis dan keterampilan hidup yang harus dimiliki siswa (North American Association for Environmental Education, 2001).

Pembelajaran berbasis lingkungan tepat jika dipadukan dengan model pembelajaran inkuiri. Inkuiri adalah suatu rangkaian kegiatan belajar yang melibatkan secara maksimal seluruh kemampuan siswa untuk mencari dan menyelidiki secara sistematis, sehingga siswa dapat merumuskan sendiri penemuannya dengan penuh percaya diri (Trianto, 2009). Pembelajaran menggunakan model inkuiri terbimbing mendorong pemahaman materi secara mendalam dan dapat meningkatkan motivasi siswa, karena tingkat keterlibatan siswa tinggi (Enggen\& Kauchak, 2012). Pembelajaran Inkuiri terdapat 3 macam yaitu inkuri bebas, inkuiri terbimbing dan inkuiri termodifikasi (Sanjaya, 2008).

Perpaduan pembelajaran inkuiri dengan pembelajaran berbasis lingkungan akan membuat siswa belajar IPA dengan aktif, mampu mengkaitkan antara materi yang didapatkan dengan lingkungannya sehingga pembelajaran bermakna dan siswa mampu secara langsung menerapkan keterampilan proses yang diisyaratkan dalam tujuan IPA pada struktur kurikulum pendidikan dasar. Hal ini sesuai dengan penelitian yang telah dilakukan Karyatin (2013) yang menyatakan bahwa pembelajaran inkuiri terbimbing dapat meningkatkan keterlaksanaan keterampilan proses IPA siswa.

Adapun keterampilan proses dasar IPA yang harus mampu dikuasai oleh siswa SD diantaranya: mengamati, mengklasifikasi, meng- 
ukur, menyimpulkan, memprediksi dan mengkomunikasikan (Amin dkk, 2006).

Studi pendahuluan telah dilakukan di kelas II pada pembelajaran IPA Madrasah Ibtidaiyah Mambaul Ulum diketahui bahwa siswa $80 \%$ pasif mengikuti pembelajaran, siswa jarang menggunakan keterampilan proses dasar IPA selama mengikuti pembelajaran, motivasi belajar rendah dan juga hasil belajar yang rendah.

Aktivitas yang muncul dalam pembelajaran IPA di kelas II Madrasah Ibtidaiyah Mambaul Ulum ini disebabkan pembelajaran hanya menggunakan metode ceramah dengan menggunakan media seadanya dalam artian hanya menggunakan lembar kerja siswa yang berasal dari penerbit serta peserta didik jarang dibawa keluar kelas untuk mempelajari suatu materi. Pembelajaran seperti ini menjadi tidak bermakna karena siswa tidak belajar secara langsung dengan lingkungan dan hanya bersifat hafalan, siswa hanya terpaku pada materi yang ada di kelas tanpa bisa menghubungkan dengan lingkungan sekitar siswa.

Berdasarkan latar belakang yang telah dipaparkan sebelumnya, maka peneliti bermaksud untuk melakukan penelitian dengan menggunakan perpaduan model pembelajaran inkuiri dengan pembelajaran berbasis lingkungan dalam mengatasi permasalahan yang dihadapi pembelajaran di kelas II MI Mambaul Ulum. Model inkuiri yang digunakan dalam penelitian ini adalah inkuiri terbimbing karena disesuaikan dengan struktur kognitif dan mental siswa kelas II yang masih membutuhkan banyak bimbingan dalam melaksanakan pembelajaran.

Adapun tujuan penelitian ini adalah mendeskripsikan pelaksanaan pembelajaran inkuiri terbimbing berbasis lingkungan pada mata pelajaran IPA di kelas II MI Mambaul Ulum Karangploso dan menjelaskan keterlaksanaan keterampilan proses dasar siswa kelas II MI Mambaul Ulum setelah pelaksanaan pembelajaran IPA menggunakan model inkuiri terbimbing berbasis lingkungan. Manfaat penelitan ini adalah untuk pengembangan inovasi pembelajaran serta alternatif peningkatan proses dan hasil belajar siswa di SD khususnya mata pelajaran IPA.

\section{METODE}

Penelitian ini menggunakan pendekatan kualitatif deskriptif. Desain penelitian menggunakan studi kasus dengan fokus pada penerapan pembelajaran inkuiri terbimbing berbasis lingkungan pada mata pelajaran IPA di Madrasah Ibtidaiyah Mambaul Ulum Karangploso.

Penelitian dilakukan di Madrasah Ibtidaiyah Mambaul Ulum Karangploso Kabupaten Malang dengan subyek penelitian adalah siswa kelas II Madrasah Ibtidaiyah Mambaul Ulum Karangploso Malang. Pengambilan sampel atau sumber data pada penelitian ini menggunakan teknik purposive sampling. Penelitian ini berusaha merekam bagaimana pelaksanaan pembelajaran inkuri terbimbing berbasis lingkungan dan keterlaksanaan keterampilan proses dasar IPA pada mata pelajaran IPA di Madrasah Ibtidaiyah Mambaul Ulum Karangploso Malang.

Teknik pengumpulan data yang digunakan pada penelitian ini adalah wawancara, observasidan tes. Instrumen penelitian terdiri dari pedoman wawancara, lembar observasi keterlaksanaan pembelajaran dan keterampilan proses dasar IPA, dan lembar tes. Peneliti berperan sebagai pengamat dan melakukan wawancara kepada informan yaitu guru dan siswa di lokasi penelitian. Penelitian ini dilakukan dalam 3 tahap dimana, pada tahap pertama peneliti mengobservasi kegiatan pembelajaran secara umum di MI Mambaul Ulum sebagai penelitian pendahuluan. Hasil penelitian pendahuluan digunakan untuk mengetahui permasalahan yang dihadapi oleh guru dan siswa. Hasil dari penelitian 
pendahuluan selanjutnya digunakan pedoman dalam melaksanakan tahap kedua.

Pada tahap kedua peneliti melakukan observasi di kelas dan melakukan wawancara kepada guru yang mengalami permasalahan. Pada tahap ketiga peneliti melakukan observasi melaksanakan pembelajaran IPA menggunakan model inkuiri terbimbing berbasis lingkungan, melakukan tes, melakukan wawancara kepada guru kelas setelah mengikuti proses pembelajaran. Hasil data dari kegiatan penelitian selanjutnya dianalisis menggunakan model Miles dan Huberman yang terdiri dari kegiatan pengumpulan data, reduksi data, penyajian data dan juga kegiatan penyimpulan. Keabsahan data dilakukan dengan proses triangulasi metode pengambilan data dan sumber data .

\section{HASIL DAN PEMBAHASAN}

Keterlaksanaan Pembelajaran Model Inkuiri Terbimbing Berbasis Lingkungan

Keterlaksanan pembelajaran menggunakan model pembelajaran inkuiri terbimbing berbasis lingkungan dimulai dari kegiatan pendahuluan. Kegiatan pendahuluan terdiri dari kegiatan memotivasi siswa, menyampaikan tujuan pembelajaran, dan menggali kemampuan awal siswa. Hasibuan (1988) menyatakan bahwa salah satu komponen dalam membuka pelajaran adalah menimbulkan motivasi.

Kegiatan inti terdiri dari langkahlangkah pembelajaran inkuiri yaitu pertama adalah pemberian masalah, pada tahap ini siswa diberikan permasalahan yang terkait dengan materi posisi matahari dan bayangan benda. Sebelum diberikan masalah siswa dibentuk dalam kelompok, saat pembentukan kelompok ini siswa tidak kondusif karena siswa tidak terbiasa melakukan kegiatan diskusi. Selanjutnya setelah terbentuk kelompok siswa diberikan sedikit pembukaan yang mengarahkan pada pemberian masalah. Pada inkuiri terbimbing siswa tidak membuat pertanyaan sendiri tetapi diberikan pertanyaan oleh guru. Pendekatan inkuiri terbimbing terjadi dimana guru membimbing siswa melakukan kegiatan dengan memberi pertanyaan awal dan mengarahkan pada suatu diskusi (Sanjaya, 2008)

Tahap berikutnya adalah pemberian masalah, pada tahap ini banyak siswa yang antusias dan termotivasi untuk menjawabnya, pertanyaan yang diajukan adalah tentang posisi matahari pada beberapa waktu. Siswa menjawab pertanyaan tersebut di lembar kerja. Lembar kerja yang dibuat oleh peneliti bersifat membimbing siswa agar siswa membuat suatu prediksi sebelum mereka melakukan pengamatan secara langsung. Saat mereka membuat prediksi ada sekitar 4 kelompok yang sudah mampu menjawab dengan benar, namun 5 kelompok sisanya masih belum bisa membuat prediksi dengan benar. Dari 5 kelompok tersebut kebanyakan masih bingung untuk membayangkan posisi matahari saat pagi, siang dan sore, karena mereka masih sedikit bingung dengan arah timur dan barat. Namun mereka tetap menjawab sesuai dengan pengetahuan awal mereka tentang posisi matahari pada pagi, siang, dan sore.

Langkah selanjutnya setelah membuat prediksi, siswa mencoba untuk mengamati atau melakukan penyelidikan untuk menjawab pertanyaan yang sebelumnya telah disampaikan. Siswa melakukan pengamatan dengan menggunakan lidi yang memiliki ukuran berbeda tiap kelompok. Untuk 
menguji posisi matahari, posisi bayangan dan panjang bayangan, hal pertama yang dilakukan oleh siswa adalah tiap kelompok meletakkan lidinya di tanah sekitar pukul 11.00, selanjutnya siswa mengamati arah datangnya matahari dan tempat terbentuknya bayangan. Setelah mereka mengamati posisi matahari dan posisi bayangan selanjutnya mereka mengukur panjang bayangan lidi. Pada tahap ini ada beberapa kelompok yang masih kebingungan karena tidak terbiasa untuk melakukan pengamatan, guru harus mampu mengarahkan siswa.

Setelah mengamati posisi matahari pada pagi hari dilanjutkan mengamati posisi matahari pada saat siang hari sekitar pukul 12.00. Seperti pada pagi hari siswa juga mengamati posisi matahari, posisi bayangan, dan panjang bayangan. Pada tahap ini siswa sudah tidak bingung untuk melakukan pengamatan dan pencatatan hasil pengamatan. Selanjutnya mengamati posisi matahari setelah jam 12.00, namun untuk mengamati posisi matahari pada saat setelah jam 12.00, penelitian mengalami kendala dimana langit mulai mendung, sehingga pada keadaan tersebut peneliti tidak melanjutkan penelitian menggunakan cahaya matahari, namun peneliti menggunakan media yang telah disiapkan yaitu senter. Selanjutnya senter dibagikan kepada siswa untuk melakukan percobaan di dalam kelas. Senter tersebut diibaratkan sebagai matahari pada sore hari, selanjutnya siswa mengarahkan cahaya senter tersebut ke arah lidi. Senter diarahkan ke arah timur, karena cahaya matahari pada sore hari berada di barat dan sinarnya mengarahkan ke timur. Melalui penggunaan media senter ini, siswa tidak mengalami kesulitan saat penggunaannya karena guru selalu mengarahkan dalam melakukan pengamatan, pengukuran maupun pencatatan.

Tahap ketiga pada pelaksaaan pembelajaran inkuiri adalah siswa menyampaikan hasil pengamatan dan melakukan analisis atau menguji dugaan sementara yang telah dibuat sebelumnya. Mereka mencoba membandingkan hasil pengamatan mereka dengan jawaban sementara (prediksi) yang telah dibuat sebelumnya, akhirnya mereka mengerti letak kesalahan dugaan sementara yang telah dibuat. Disinilah kunci utama dari inkuiri dimana siswa mulai mendapat pengetahuan dari permasalahan dan siswa menemukan jawaban sendiri setelah mengalami secara langsung. Pembelajaran inkuiri adalah rang-kaian kegiatan pembelajaran yang menekankan pada proses berpikir kritis dan analitis untuk mencari dan menemukan jawaban sendiri dari suatu masalah yang dipertanyakan (Hamruni, 2012).

Hal ini juga sesuai dengan teori Piaget bahwa siswa dihadapkan pada penggunaan konsep baru dan mengubah konsep baru tersebut agar sesuai dengan model mental yang sudah dimilikinya (asimilasi) kemudian menyesuaikan model mental yang sudah ada agar sesuai dengan konsep baru tersebut (akomodasi) (Desmita, 2010).

Langkah terakhir siswa membuat kesimpulan. Pada tahap ini siswa tidak mengalami kesulitan dalam membuat kesimpulan karena guru telah mengarahkan dengan kata-kata yang mudah dipahami dan siswa hanya melengkapi tempat yang kosong dengan hasil pengamatan yang mereka dapatkan. Pada bagian penutup dilakukan tanya jawab serta siswa diajak untuk mengingat kembali tentang materi yang telah 
dibahas sebelumnya. Selnjutnya pada akhir kegiatan siswa melakukan latihan.

Secara umum diketahui bahwa pembelajaran inkuiri terbimbing berbasis lingkungan pada materi posisi matahari telah terlaksana dan sesuai dengan langkahlangkah pembelajaran inkuiri terbimbing sebesar $91 \%$ berdasarkan lembar keterlaksanaan. Kegiatan inkuiri terdiri dari kegiatan menyajikan pertanyaan, membuat hipotesis, melakukan percobaan untuk memperoleh informasi, menguji hipotesis dan membuat kesimpulan (Enggen \& Kuachak (1996).

Pemilihan model inkuiri terbimbing disebabkan siswa tidak terbiasa melakukan kegiatan inkuri serta perkembangan kognitif dan mentalnya belum mampu jika menggunakan inkuiri bebas. Pendekatan inkuiri terbimbing ini digunakan bagi siswa yang kurang berpengalaman belajar dengan pendekatan inkuiri (Sanjaya, 2008).

Pembelajaran IPA di kelas II MI Mambaul Ulum pada penelitian ini juga telah mencakup asas-asas pembelajaran berbasis lingkungan, karena permasalahan yang dikaji adalah permasalahan yang sangat dikenal siswa, media yang digunakan ada di lingkungan siswa seperti cahaya matahari dan lidi. Pembelajaran berbasis lingkungan adalah pembelajaran yang mengintegrasikan unsur lingkungan dalam proses pembelajaran yang bertujuan untuk membantu peserta didik mendapatkan makna dari pembelajaran (Wiyarsi dan Sari, 2010).

Pembelajaran berbasis lingkungan sesuai dengan teori Piaget bahwa anak usia SD aktivitas mentalnya difokuskan pada objek-objek dan peristiwa nyata dapat diukur, anak telah mampu membedakan apa yang tampak oleh mata dengan kenyataan sesungguhnya (Desmita, 2011).

Pelaksanaan pembelajaran inkuiri terbimbing berbasis lingkungan mengalami beberapa kendala seperti kondisi kelas yang kurang kondusif, membutuhkan waktu yang cukup lama, dan siswa banyak yang belum terbiasa bekerja dalam kelompok serta melakukan pengamatan, akibatnya pada awal kegiatan diskusi dan pengamatan banyak siswa yang masih bingung untuk melaksanakan kegiatan yang diminta oleh guru. Kelemahan dari penggunaan model inkuiri diantaranya sulit mengontrol kegiatan, implementasinya membutuhkan waktu yang panjang dan tidak mudah mendesainnya karena terbentur dengan kebiasaan siswa (Hamruni, 2011).

Kendala-kendala yang dihadapi dalam proses pembelajaran inkuiri terbimbing berbasis lingkungan menuntut peran guru dalam membimbing dan mengarahkan siswa dalam melaksanakan langkah-langkah pembelajaran inkuiri termbimbing. Guru dalam inkuiri terbimbing mempunyai peran aktif dalam menentukan permasalahan dan tahap-tahap pemecahannya (Sanjaya, 2008).

Hasil wawancara dengan beberapa siswa diketahui siswa antusias dan termotivasi mengikuti pembelajaran, karena pembelajaran tidak dilakukan seperti biasanya yang hanya ceramah, permasalahan yang disajikan dalam kehidupan sehari-hari sehingga siswa kenal, siswa juga merasa tertantang atau memiliki rasa ingin tahu yang cukup tinggi karena mereka harus membuktikan dugaan sementara yang mereka buat sebelum melakukan kegiatan pengamatan. Model inkuiri efektif untuk meningkatkan motivasi siswa, karena tingkat keterlibatan tinggi, jaminan keberhasilan, 
dan perasaan misteri merupakan ciri-ciri pembelajaran inkuiri (Enggen\& Kauchak, 2012).

Pembelajaran inkuiri terbimbing berbasis lingkungan sesuai dengan teori pematangan otak yang harus diiringi dengan peluang-peluang untuk mengalami suatu dunia yang makin luas, dengan cara mendorong anak untuk mencari dan meneliti apa yang dikehendakinya. Pembelajaran seperti ini akan mendorong anak untuk berpikir, mengamati, merenungkan dan menemukan secara kreatif. Proses pembelajaran yang ideal bagi anak adalah tidak menjajalkan pengetahuan secara berlebihan yang nanti justru akan mengganggu pemahaman dan melelahkan otak anak sehingga dapat mematikan kecerdasan (Desmita, 2010).

\section{Keterampilan Proses Dasar IPA}

Keterampilan proses dasar IPA yang dilatihkan pada penelitian ini adalah mengamati, mengklasifikasikan, mengukur, memprediksi, menyimpulkan dan mengkomunikasikan (Amin dkk, 2006). Berikut data keterampilan proses dasar yang ditunjukkan siswa kelas II MI Mambaul Ulum setelah mengikuti pembelajaran inkuiri terbimbing berbasis lingkungan.

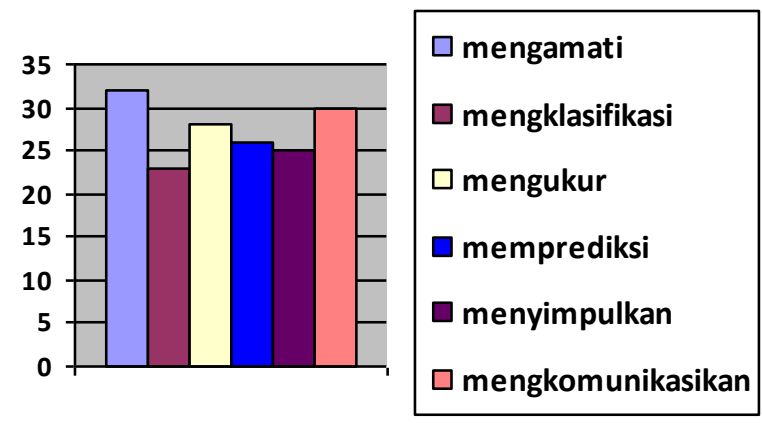

Gambar 1.1 Keterampilan proses dasar IPA setelah melaksanakan pembelajaran
Berdasarkan gambar 1.1 diketahui bahwa keterampilan proses dasar IPA mengamati sebanyak 32 dari 32 siswa atau sekitar $100 \%$. Keterampilan proses dasar mengamati telah terlihat pada semua siswa khususnya pada materi ini adalah letak posisi matahari, posisi bayangan benda dan panjang bayangan benda. Siswa tidak bingung saat diminta untuk mengamati. Kemampuan mengamati tidak memerlukan kegiatan seperti harus mampu membaca, sehingga siswa dengan mudah mengamati karakteristik objek yang diamati.

Keterampilan proses dasar yang kedua adalah mengklasifikasi sebesar $71,8 \%$. Pada penelitian ini kegiatan mengklasifikasi dengan cara mengelompokkan panjang bayangan hasil pencahayaan matahari yang lebih panjang dan lebih pendek. Pada keterampilan proses dasar ini ditunjukkan cukup sedikit disebabkan siswa masih sedikit kebingungan membedakan bayangan yang lebih panjang dari benda asli dengan bayangan yang lebih pendek dari benda aslinya, karena siswa belum terbiasa membandingkan panjang atau pendek suatu benda, dalam mempermudah siswa guru membantu menuntun membedakan bayangan yang lebih panjang dan bayangan yang lebih pendek.

Keterampilan proses selanjutnya adalah mengukur, kemampuan mengukur siswa setelah mengikuti pembelajaran IPA menggunakan inkuiri terbimbing berbasis lingkungan terlihat sekitar $87,5 \%$ atau 28 siswa dari 32 siswa. Sisanya $12,5 \%$ disebabkan siswa tidak dapat membaca sebanyak 2 anak dan sisanya masih bingung dalam mengukur, masih ada siswa yang mengukur dimulai tidak dari angka nol dan menggunakan penggaris tidak lurus. 
Kegiatan mengukur pada penelitian ini adalah mengukur panjang benda dan panjang bayangan benda setelah mendapatkan sinar matahari.

Keterampilan proses yang keempat adalah memprediksi. Keterampilan proses dasar IPA ini terlihat sekitar $81,25 \%$ dari jumlah siswa atau sekitar 25 siswa. Kegiatan memprediksi pada penelitian ini adalah siswa mencoba memprediksikan posisi matahari dan bayangan benda pada waktu pagi, siang dan sore hari. Ada sekitar 25 siswa yang telah disebutkan sebelumnya dapat memprediksikan jawabannya dan sisanya sekitar 7 siswa masih belum mengerti dan tidak menjawab apa yang diminta oleh guru, selain itu ada 2 orang siswa yang tidak dapat membaca.

Keterampilan proses dasar yang kelima adalah menyimpulkan. Keterampilan proses dasar ini terlihat sekitar 81,25\%, siswa kelas II masih ada yang belum mengerti cara menyimpulkan dari hasil percobaan, sehingga diperlukan bimbingan guru dalam membimbing siswa untuk dapat menyimpulkan. Pada penelitian ini dipermudah oleh guru dengan cara guru membuat pernyataan sehingga siswa hanya melanjutkan pernyataan tersebut.

Keterampilan proses dasar yang terakhir adalah mengkomunikasikan pada tahap ini diketahui sekitar $93,75 \%$ sudah mampu mengkomunikasikan hasil diskusi dengan temannya cukup baik, namun masih ada 2 orang yang belum bisa menunjukkan hal tersebut karena 2 siswa tersebut tidak bisa membaca.

Hasil menyatakan secara umum keterampilan proses dasar yang dilatihkan kepada siswa telah muncul dan berkembang cukup baik dengan prosentase yang cukup variatif. Hal ini disebabkan proses dalam pembelajaran IPA menggunakan model pembelajaran inkuiri terbimbing berbasis lingkungan sesuai digunakan guru untuk melatihkan keterampilan proses dasar IPA, sebab langkah-langkah dalam pembelajaran inkuiri terbimbing berbasis lingkungan telah mencakup keterampilan proses dasar yang disyaratkan dalam pembelajaran IPA. Misalnya, pada tahap kedua membuat hipotesis siswa berusaha membuat suatu prediksi, pada tahap ketiga siswa melakukan percobaan untuk mengumpulkan data, dimana kegiatan yang dilakukan adalah mengamati posisi matahari dan bayangan benda serta mengukur panjang benda dan bayangan benda. Dilanjutkan melakukan analisis data dimana siswa mencoba mengklasifikasikan data dengan cara mengelompokkan bayangan yang lebih pendek dan lebih panjang dari benda aslinya. Tahap selanjutnya siswa menyimpulkan dari hasil analisis yang telah dilakukan. Pada tahap terakhir siswa mengkomunikasikan hasil dari kesimpulan yang telah didiskusikan. Pembelajaran inkuiri akan membuat siswa lebih menyadari tentang proses penyelidikannya (keterampilan proses) dan mereka dapat diajarkan tentang prosedur 5 langkah inkuri (Suchman dalam Trianto, 2009).

Paparan data yang diperoleh diketahui siswa yang kurang mampu dalam beberapa aspek secara keseluruhan adalah 2 orang siswa yang mana mereka belum bisa membaca sehingga siswa sulit mengikuti kegiatan pembelajaran, karena kesulitan membaca, hampir semua kegiatan sulit diikuti oleh kedua orang siswa tersebut. Pada akhirnya hasil belajar yang didapatkannya adalah nol tau tidak bisa mengerjakan sama 
sekali. Siswa dapat mengerjakan jika diberikan bantuan oleh guru misalnya dibacakan.

Nilai kedua siswa ini juga berpengaruh terhadap nilai rata-rata hasil belajar siswa setelah mengikuti kegiatan pembelajaran menggunakan model pembelajaran inkuiri terbimbing berbasis lingkungan. Jika tanpa ditambahkan kedua nilai siswa tersebut, nilai rata-rata sebesar 82 , sedangkan jika ditambahkan dengan nilai kedua siswa tersebut rata-rata menjadi hanya 77.

Nilai kedua siswa ini berpengaruh terhadap rata-rata hasil belajar siswa sebab nilai dari kedua siswa ini adalah nol, dikarenakan siswa tersebut tidak bisa membaca. Padahal menurut Havighurst, tugas perkembangan anak usia sekolah dasar salah satunya adalah belajar membaca, menulis dan berhitung agar mampu berpastisipasi dalam masyarakat (Desmita, 2011). Menghadapi fenomena seperti ini diperlukan perhatian khusus bagi kedua siswa, perhatian tidak hanya dari guru, tetapi juga dari keluarga. Peran keluarga sangat berpengaruh terhadap pola pikir dan kebiasaan siswa. Ki Hajar Dewantara, menegaskan bahwa: Pendidikan harus dilakukan secara kooperatif antara keluarga, sekolah dan masyarakat. Keluarga merupakan pusat pendidikan pertama dan terpenting, karena keluargalah pondasi utama pembentukan Intelligence Quotient (IQ) dan Emotional Quotient (EQ) (Raharja, 2013)

Pada aspek hasil belajar siswa didapatkan hasil yang cukup baik setelah mengikuti pembelajaran yaitu rata-rata sekitar 82 tanpa siswa yang tidak bisa membaca. Hasil yang meningkat cukup signifikan dibandingkan menggunakan metode ceramah sebelumnya sejalan dengan Indirawati (dalam Trianto 2009) yang menyatakan suatu pembelajaran akan lebih efektif bila diselenggarakan melalui model pembelajaran yang menekankan kemampuan berpikir terhadap suatu masalah dan mengolah informasi seperti pada kegiatan inkuiri. Kegiatan penelitian ini juga didukung pembelajaran berbasis lingkungan yang membuat siswa lebih merasa termotivasi dan bermakna karena siswa telah mengenal permasalahan yang ada di sekitar siswa. Pembelajaran berbasis lingkungan berusaha membuat siswa mendapatkan makna dan pemahaman dari proses pembelajaran serta dengan mudah siswa dapat mengkonstruksikan ilmu yang didapatkannya (Wiyarsi dan Sari, 2010)

\section{KESIMPULAN}

Berdasarkan analisis hasil dan pembahasan dapat disimpulkan sebagai berikut:

1. Pembelajaran IPA menggunakan model pembelajaran inkuiri terbimbing berbasis lingkungan telah terlaksana dengan baik sesuai dengan langkah yang ditentukan sebesar 90,9 \% serta siswa kelas II mampu melaksanakannya dengan baik

2. Keterampilan proses dasar IPA yang dilatihkan di kelas II MI Mambaul Ulum menggunakan model pembelajaran Inkuiri terbimbing berbasis lingkungan telah terlihat pada semua aspek, dengan prosentase dari $71,8 \%-100 \%$.

3. Hasil belajar siswa meningkat dibandingkan menggunakan metode konvensional 


\section{SARAN}

Berdasarkan penelitian yang telah dilakukan, diberikan beberapa saran dimana sebelum melaksanakan pembelajaran menggunakan inkuiri terbimbing sebelumnya dipersiapkan perencanaan pengelolaan waktu dan pengelolaan kelas.

\section{DAFTAR PUSTAKA}

Amin, M. ;Wahono, W.; Chandra,D.; Rinie, P. ; Sulastri, S.dan Sumartini. 2006. Paduan Pengembangan Bahan Ajar IPA. Direktorat Pembinaan SMP.

Desmita. 2011. Psikologi Perkembangan Peserta Didik. Bandung : Remaja Rosda Karya

Enggen dan Kauchak. 2012. Strategi dan Model Pembelajaran. Edisi Keenam. Terjemahan: Satrio Wahono. Jakarta: Indeks

Hamruni. 2012. Strategi Pembelajaran. Yogyakarta: Insan Madani.

Hasibuan dan Moedjiono. 1988. Proses Belajar Mengajar. Bandung: Remaja Rosdakarya.
Karyatin. 2013. Penerapan Pembelajaran

Inkuiri Terbimbing Berbasis

Laboratorium untuk Meningkatkan

Keterampilan Proses dan Hasil

Belajar IPA Siswa Kelas VIII-4 SMPN

1 Probolinggo Malang: Universitas

Negeri Malang.

North American Association for Environmental Education, 2001. Using Environment Based Education to Advance Learning Skills and Character Development. Washington: North American Association for Environmental Education.

Raharja, U. 2013. Pengantar Pendidikan. Bandung: Remaja Rosdakarya.

Sanjaya, Wina. 2008. Strategi Pembelajaran Berorientasi Standar Proses Pendidikan. Kencana Prenada Media Group. Jakarta

Trianto. 2009. Mendesain Model Pembelajaran Inovatif-Progresif, Konsep, Landasan dan Implementasinya pada KTSP. Jakarta: Kencana Prenada Media Group.

Wiyarsi, A. dan Sari,L. 2010. Efektivitas Penerapan Pendekatan Kontekstual Berbasis Alam Terhadap Sikap Ilmiah dan Prestasi Belajar Kimia Siswa SMA di Yogyakarta. Yogyakarta: Universitas Negeri Yogyakarta. 